\title{
GAMBARAN KEJADIAN BERAT BADAN LAHIR RENDAH DI KABUPATEN PATI
}

\section{INCIDENT DESCRIPTION OF LOW BIRTH WEIGHT IN PATI REGENCY}

\author{
Aeda Ernawati \\ Kantor Penelitian dan Pengembangan Kabupaten Pati \\ Email: aeda.ernawati@yahoo.com
}

Naskah Masuk: 27 Maret 2015 Naskah Revisi: 6 April 2015 Naskah Diterima: 20 April 2015

\begin{abstract}
Low Birth Weight is one of the health problems during neonatal period. The purpose of this study is to describe Low Birth Weight (LBW) incidences in Pati Regency, include time, sex, place, and contributing for neonatal mortalities. This research used descriptive and quantitative approaches. Data sources derived from secondary data, i.e. Low Birth Weight records in Pati Regency 2011 2014. Data were analyzed descriptively. Results of study are the percentage of Low Birth Weight (LBW) incidence in Pati Regency in 2014 was $3.19 \%$ and it tended to increase from the previous year. Based on infant's sex, there was slight different percentage between male infant and female infant (about 0.09\% to 0.17\%). The highest percentage of LBW in 2014 was found in Community Health Center (Puskesmas) of Winong 2, i.e. 6.69\%. Period 2011-2014, LBW was the prior determinant of neonatal mortality in every year with the percentage ranged 32-45\%. Threathment and prevention for $L B W$ should become priority to decrease neonatal mortality.
\end{abstract}

Keywords: $L B W$, neonatal mortality, sex

\begin{abstract}
ABSTRAK
Berat Badan Lahir Rendah (BBLR) merupakan salah satu masalah kesehatan pada masa neonatal. Tujuan penelitian untuk menggambarkan kejadian BBLR di Kabupaten Pati berdasarkan waktu, jenis kelamin, tempat dan kontribusinya terhadap kematian neonatal. Penelitian ini menggunakan pendekatan deskriptif kuantitatif. Sumber data berasal dari data sekunder berupa data BBLR di Kabupaten Pati tahun 2011-2014 kemudian dianalisis secara deskriptif. Hasil penelitian menunjukkan angka kejadian BBLR di Kabupaten Pati tahun 2014 sebesar 3,19\% dan ada kecenderungan meningkat dari tahun sebelumnya. Persentase BBLR pada bayi laki-laki berbeda dengan persentase BBLR pada bayi perempuan, meskipun perbedaannya tidak terlalu jauh yaitu sekitar 0,09\% sampai 0,17\%. Angka kejadian BBLR tertinggi tahun 2014 terjadi di Puskesmas Winong 2 yaitu sebanyak 6,69\%. BBLR menjadi penyebab kematian neonatal terbesar yaitu sekitar $32-45 \%$ setiap tahun. Penanganan dan pencegahan BBLR menjadi prioritas dalam rangka menurunkan angka kematian neonatal.
\end{abstract}

Kata kunci: BBLR, jenis kelamin, kematian neonatal 


\section{PENDAHULUAN}

Upaya pemeliharaan kesehatan anak dilakukan sejak janin dalam kandungan, dilahirkan, setelah dilahirkan, dan sampai berusia 18 tahun. Upaya ditujukan untuk mempersiapkan generasi yang sehat, cerdas, dan berkualitas di masa depan. Selain itu, upaya kesehatan bertujuan untuk menurunkan angka kematian anak (Kemenkes RI, 2014).

Terdapat beberapa indikator yang berhubungan dengan kondisi kesehatan anak yaitu Angka Kematian Neonatal (AKN), Angka Kematian Bayi (AKB) dan Angka Kematian Balita (AKABA). Hasil Survey Demografi dan Kesehatan Indonesia (SDKI) tahun 2012 menunjukkan AKN pada tahun 2012 sebesar 19 per 1000 kelahiran hidup dan AKB sebesar 32 per 100 kelahiran hidup. Pencapaian ini masih jauh dari target penurunan AKB pada MDGs yaitu sebesar 23 per 1000 kelahiran hidup pada tahun 2015. Salah satu upaya penting untuk menurunkan AKB yaitu dengan memberikan perhatian pada upaya penurunan angka kematian neonatal (0-28 hari) mengingat kematian neonatal memberikan kontribusi terhadap 56\% kematian bayi. Salah satu masalah kesehatan pada masa neonatal adalah Berat Barat Lahir Rendah. Berat Badan Lahir Rendah (BBLR) adalah bayi dengan berat lahir kurang dari 2500 gram (Kemenkes RI, 2014).

Sampai saat ini BBLR masih menjadi masalah kesehatan di negara berkembang. Kejadian BBLR di negara berkembang empat kali lebih besar dibandingkan di negara maju. Kejadian BBLR sekitar 15-17\% dari angka kelahiran hidup dan $95 \%$ berada di negara berkembang (Suryadi, 2010). Kejadian BBLR di Indonesia berdasarkan hasil Riskesdas 2013 dalam Profil Kesehatan Indonesia (2014) menunjukkan persentase balita (0-59 bulan) dengan BBLR sebesar $10,2 \%$. Persentase BBLR tertinggi terdapat di Provinsi Sulawesi Tengah $(16,8 \%)$ dan terendah di Sumatera Utara (7,25\%). Profil Kesehatan Provinsi Jawa Tengah tahun 2013 menunjukkan persentase BBLR di Provinsi Jawa Tengah sebesar 3,75\% atau sama dengan tahun sebelumnya. Tingginya angka kejadian BBLR merupakan masalah kesehatan karena BBLR menjadi salah satu penyebab utama kematian neonatal. Sebanyak $15-20 \%$ kematian bayi di Indonesia disebabkan karena BBLR (Depkes RI, 2008).

Tujuan MDGs untuk menurunkan kematian anak akan tercapai melalui upaya memastikan kondisi kesehatan anak pada fase awal kehidupan. Berat badan lahir merupakan indikator penting kesehatan bayi dan merupakan faktor determinan keberlangsungan hidup serta pertumbuhan fisik dan mental bayi di masa yang akan datang. Menurut UNICEF dan WHO (2004), penurunan kejadian BBLR merupakan salah satu kontribusi penting dalam pencapaian komitmen MDGs untuk menurunkan angka kematian bayi (Anonim, 2013).

Berdasarkan Profil Kesehatan Provinsi Jawa Tengah tahun 2014, BBLR masih terjadi di Kabupaten Pati. Tujuan penelitian ini untuk menggambarkan kejadian BBLR di Kabupaten Pati berdasarkan waktu (tahun 2011-2014), jenis kelamin, tempat serta kontribusinya terhadap kematian neonatal.

\section{TINJAUAN PUSTAKA}

\section{Pengertian dan Klasifikasi Berat Badan Lahir Rendah}

Berat badan lahir adalah berat badan bayi yang ditimbang dalam waktu 1 jam pertama setelah lahir. Berkaitan dengan berat badan bayi lahir, bayi dapat dikelompokkan menjadi 3 (tiga) yaitu: 1) Berat Badan Lahir Rendah (BBLR) yaitu bayi dengan berat lahir $<2500$ gram; 2) berat badan berat lahir sedang, yaitu berat 
lahir antara 2500-3999 gram; dan 3) berat badan lahir lebih yaitu berat lahir $\geq 4000$ gram (Kemenkes, 2014).

Berdasarkan penanganan dan harapan hidupnya, Saifuddin (2001) membagi BBLR menjadi 3, yaitu; 1) Berat Badan Lahir Rendah (BBLR) jika berat lahir 1500-2499 gram; 2) Berat Badan Lahir Sangat Rendah (BBLSR) jika berat lahir 1000-1499 gram; 3) Berat Badan Lahir Ekstrem Rendah (BBLER) jika berat lahir <1000 gram.

Berdasarkan usia kehamilan, Sistiarani (2008) membagi bayi dengan berat badan lahir rendah menjadi 2 tipe yaitu: 1) Bayi prematur dan ;2) Bayi Kecil untuk Masa Kehamilan (KMK). Makin rendah masa gestasi dan makin kecil bayi yang dilahirkan makin tinggi morbiditas dan mortalitasnya. Gangguan pada bayi prematur akan dapat diatasi dengan penanganan yang optimal dan menggunakan alat yang memadai. Bayi prematur dapat dibedakan menjadi 3 kelompok berdasarkan batas timbulnya permasalahan pada derajat prematuritas yaitu: 1) Bayi yang sangat prematur, dengan masa gestasi 24-30 minggu; 2) Bayi dengan derajat prematur sedang, yaitu masa gestasi 31-36 minggu; dan 3) Borderline premature, yaitu bayi dengan masa gestasi 37-38 minggu.

KMK dibagi atas: 1) Proportionate Intra Uterin Growth Retardation, adalah janin lahir dengan berat, panjang, dan lingkaran kepala dalam proporsi yang seimbang, akan tetapi keseluruhannya masih di bawah masa gestasi yang sebenarnya; 2) Disproportionate Intra Uterin Growth Retardation, adalah janin lahir dengan panjang dan lingkaran kepala normal akan tetapi berat tidak sesuai dengan masa gestasi.

\section{Komplikasi BBLR}

BBLR kurang bulan atau prematur lebih mudah terkena komplikasi karena alat tubuh bayi belum berfungsi seperti bayi matur. Masalah-masalah yang terjadi pada bayi BBLR cukup bulan (aterm) yaitu asfiksia perinatal, hipoglikemia, polisitemia-hiperviskositas, hipotermi, dan dismorfologi. Sedangkan masalahmasalah yang umum terjadi pada bayi BBLR kurang bulan (prematur) yaitu dysplasia bronkopulmonial, apnea, duktus arterious paten, bradikardi, hiperbilirubin, perdarahan subkutan, fungsi saluran pencernaan jelek, hipokalsemia, hipoglikemia, hiperglikemia, perdarahan intraventrikular, hipotonia, hiponatremia, hipermatremia dan hiperklasemia. Oleh karena itu, bayi prematur mengalami lebih banyak kesulitan hidup di luar uterus. Makin pendek masa kehamilannya makin kurang sempurna pertumbuhan alat-alat dalam tubuhnya dengan akibat makin mudahnya komplikasi dan makin tingginya angka kematiannya. Sedangkan BBLR cukup bulan memiliki kemampuan untuk bertahan hidup lebih baik daripada bayi prematur karena alat-alat tubuhnya sudah terbentuk sempurna (Mutianingsih, 2013).

Bayi BBLR berisiko tinggi mengalami sepsis neonatorum karena pada bayi dengan BBLR, pematangan organ tubuhnya (hati, paru, enzim, pencernaan, otak, daya pertahanan tubuh terhadap infeksi, dan lain-lain) belum sempurna. Maka bayi BBLR sering mengalami komplikasi yang berakhir dengan kematian. Minggu pertama setelah bayi lahir pada bayi dengan berat badan normal, berat badannya akan turun kemudian akan naik sesuai dengan grafik pertumbuhan bayi. Sedangkan bayi dengan BBLR berat badannya dapat turun setiap saat, karena biasanya ada masalah dalam pemberian Air Susu Ibu (ASI). Kondisi ini terjadi akibat bayi kurang atau tidak mampu mengisap ASI, bayi menderita infeksi atau mengalami kelainan bawaan (Simbolon, 2006). 


\section{Faktor Resiko Terjadinya BBLR}

Faktor risiko terjadinya BBLR dapat berasal dari ibu maupun janin. Faktor yang berasal dari ibu antara lain umur ibu, usia kehamilan, paritas, kadar haemoglobin, dan penyakit yang diderita ibu seperti pre eklampsia, eklampsia dan diabetes mellitus. Adapun faktor janin antara lain kehamilan ganda dan volume amnion (Suryadi, 2010).

Usia ideal bagi perempuan untuk hamil adalah 20-35 tahun. Kehamilan pada usia di bawah dan usia lebih dari 35 tahun termasuk kehamilan berisiko melahirkan bayi BBLR (Ernawati, 2013). Kehamilan pada ibu dengan usia kurang dari 20 tahun berisiko melahirkan bayi BBLR karena ibu hamil masih dalam masa pertumbuhan sehingga asupan makanan pada usia tersebut banyak digunakan untuk mencukupi kebutuhan ibu (Sistiarani, 2008). Sedangkan pada ibu yang sudah tua, BBLR dapat terjadi karena kondisi kesehatan ibu mulai menurun sehingga dapat mempengaruhi janin dalam rahim (Himawan, 2006).

Usia kehamilan merupakan faktor risiko terjadinya BBLR. Usia kehamilan mempengaruhi pematangan organ dan efektivitas penyaluran nutrisi dan oksigenasi plasenta yang dibutuhkan janin untuk tumbuh optimal. Jika bayi dilahirkan pada usia kehamilan kurang bulan (28-36 minggu), pematangan organ yang belum sempurna dan kurangnya penyaluran nutrisi dan oksigenasi membuat janin tumbuh tak optimal. Hal ini membuat bayi mempunyai berat badan lahir yang rendah (Suryadi, 2010).

Ibu dengan paritas lebih dari empat anak berisiko 2,4 kali lebih besar untuk melahirkan BBLR karena setiap proses kehamilan dan persalinan menyebabkan trauma fisik dan psikis. Semakin banyak trauma yang ditinggalkan menyebabkan penyulit pada kehamilan dan persalinan berikutnya. Kehamilan anak ke empat atau lebih menyebabkan kemunduran daya lentur (elastisitas) jaringan yang sudah berulang kali direnggangkan oleh kehamilan sehingga cenderung untuk timbul kelainan letak ataupun kelainan pertumbuhan plasenta dan pertumbuhan janin. Kondisi ini mempengaruhi suplai gizi ibu ke janin sehingga berisiko melahirkan bayi dengan BBLR (Asiyah, 2010).

Anemia saat hamil dapat menyebabkan gangguan nutrisi dan oksigenasi uteroplasenta yang berakibat pada gangguan pertumbuhan janin. Kadar haemoglobin di bawah 11 gram \% mempunyai hubungan signifikan dengan kejadian BBLR, terbukti dengan adanya kecenderungan kejadian BBLR dilahirkan oleh $42 \%$ dari ibu hamil yang mengalami anemia (Suryadi, 2010).

Suplai darah ke janin pada kehamilan ganda harus terbagi dua atau lebih untuk masing-masing janin sehingga suplai nutrisi berkurang. Kondisi ini memungkinkan terjadinya Berat Badan Lahir Rendah (BBLR). Berat badan janin pada kehamilan kembar lebih ringan daripada janin pada kehamilan tunggal pada umur kehamilan yang sama. Kenaikan berat badan janin kembar sampai usia kehamilan 30 minggu, sama dengan kehamilan janin tunggal. Setelah itu, kenaikan berat badan lebih kecil karena regangan yang berlebihan sehingga menyebabkan peredaran darah plasenta berkurang. Berat badan satu janin pada kehamilan kembar rata-rata 1000 gram lebih ringan dari pada kehamilan tunggal (Prawirohardjo, 2007).

\section{Cara Mengukur Besarnya Permasalahan BBLR}

Besarnya permasalahan BBLR di suatu wilayah dinilai berdasarkan persentase Berat Badan Lahir Rendah (BBLR) dibandingkan jumlah seluruh bayi yang lahir hidup yang dirumuskan sebagai berikut: 
Jumlah bayi lahir yang ditimbang

dengan berat kurang dari 2500 gram

$\begin{array}{lll}\text { Persentase bayi } & \text { - } \\ \text { dengan BBLR } & \text { Jumlah Bayi Lahir Hidup } & \text { x 100\% }\end{array}$

\section{METODE PENELITIAN}

Penelitian menggunakan pendekatan deskriptif kuantitatif. Data berupa data sekunder, yaitu catatan BBLR di Kabupaten Pati tahun 2011-2014. Data diperoleh dari dokumen Dinas Kesehatan Kabupaten Pati yang dianalisis secara deskriptif.

\section{HASIL DAN PEMBAHASAN}

Setiap orang tua berharap agar bayi yang dikandungnya lahir dengan sehat dan selamat. Realitas menunjukkan bahwa kehamilan ada yang berakhir dengan bayi lahir mati dan lahir hidup. Diantara bayi yang lahir hidup tersebut, ada bayi yang mengalami BBLR. Bayi yang mengalami BBLR ada yang bertahan hidup dan ada yang meninggal dunia. BBLR menjadi salah satu sebab kematian bayi pada masa neonatal. Data bayi lahir mati, lahir hidup, jumlah BBLR, jumlah BBLR yang meninggal dan jumlah kematian pada masa neonatal di Kabupaten Pati disajikan dalam tabel 1.

Tabel 1.

Jumlah Bayi Lahir Mati, Bayi Lahir Hidup, Jumlah BBLR, Jumlah BBLR yang Meninggal dan Jumlah Kematian Neonatal di Kabupaten Pati Tahun 2011-2014

\begin{tabular}{cccccccccccc}
\hline \multirow{2}{*}{ Tahun } & \multicolumn{3}{c}{ Bayi lahir Hidup } & \multicolumn{4}{c}{ Bayi lahir Mati } & \multicolumn{3}{c}{ BBLR } & BBLR \\
\cline { 2 - 7 } & P & L & Total & P & L & Total & P & L & Total & Kematian \\
meninggal & Neonatal \\
\hline 2011 & 9559 & 9716 & 19275 & 64 & 84 & 148 & & & 577 & 56 & 140 \\
2012 & 9504 & 10151 & 19655 & 71 & 82 & 153 & 308 & 312 & 620 & 64 & 141 \\
2013 & 9197 & 9245 & 18442 & 68 & 97 & 166 & 288 & 281 & 569 & 49 & 149 \\
2014 & 8582 & 9355 & 17937 & 63 & 81 & 144 & 267 & 305 & 572 & 55 & 137 \\
\hline
\end{tabular}

Sumber: Dinkes Kab. Pati (2011-2014).

Jumlah bayi lahir di Kabupaten Pati tahun 2013 dan 2014 lebih rendah dari tahun-tahun sebelumnya. Hal ini mungkin disebabkan angka kelahiran kasar yang menurun. BPS Kabupaten Pati (2014) menyebutkan jumlah penduduk Kabupaten Pati tahun 2012 adalah 1.210.025 jiwa sedangkan tahun 2013 adalah 1.218.016 jiwa. Berdasarkan data tersebut dapat dihitung angka kelahiran kasar Kabupaten Pati. Hasilnya menunjukkan angka kelahiran kasar tahun 2013 sebesar 15,28 lebih rendah dari angka kelahiran kasar tahun 2012 (16,37).

\section{Angka Kejadian BBLR}

Angka kejadian BBLR di Kabupaten Pati dalam empat tahun terakhir bervariasi dari tahun ke tahun. Angka kejadian tertinggi tahun 2014 sebesar 3,19\% sedangkan angka terendah terjadi pada tahun 2011 sebesar 2,99\%. Angka kejadian BBLR di Kabupaten Pati masih lebih rendah dibandingkan angka BBLR Provinsi Jawa Tengah tahun 2013 yang besarnya $3,75 \%$. Profil Kesehatan Indonesia tahun 2013 menyebutkan kejadian BBLR pada balita secara nasional berdasarkan Riskesdas tahun 2013 sebesar 10,2\%.

Berdasarkan data BBLR dari tahun 2011-2014, ada kecenderungan BBLR meningkat sesuai Gambar 1. 


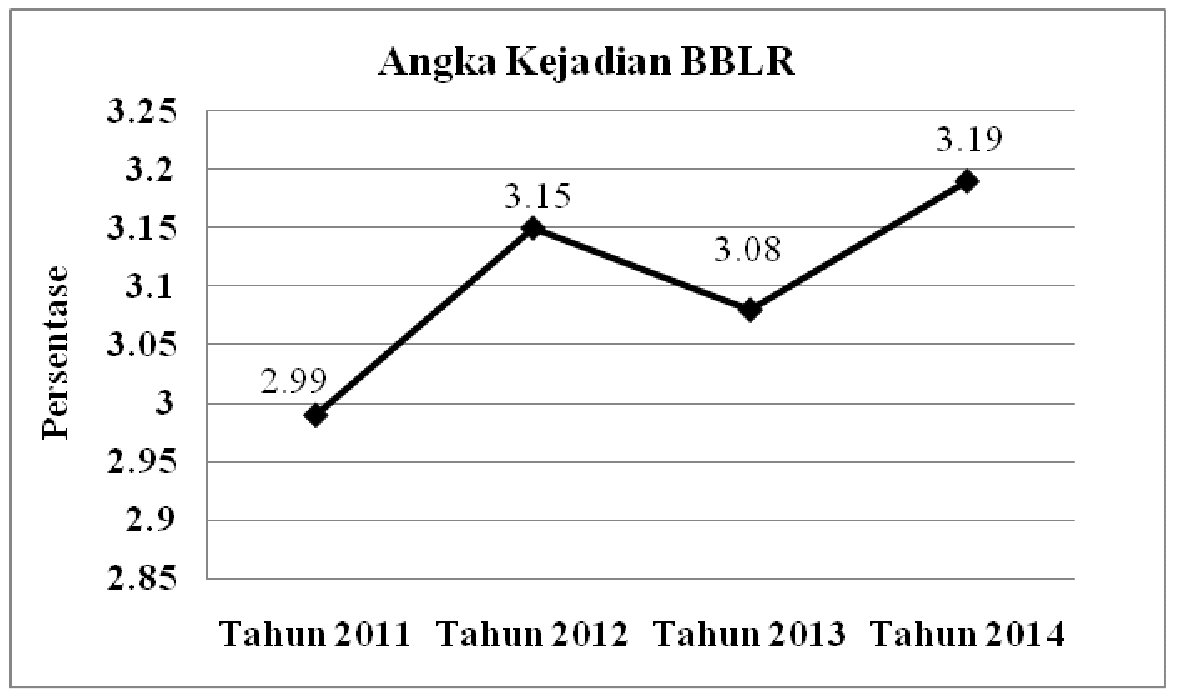

\section{Gambar 1.}

Angka Kejadian BBLR di Kabupaten Pati Tahun 2011-2014

Sumber: Dinkes Kab. Pati (2011-2014)

Kecenderungan Peningkatan BBLR perlu diwaspadai karena dapat menyebabkan kematian pada bayi. Penelitian oleh Sistiarani (2008) membuktikan bahwa neonatal dengan BBLR berisiko mengalami kematian 6,5 kali lebih besar dari pada bayi yang lahir dengan berat badan normal. Analisis data kematian bayi di Kabupaten Pati rentang waktu 2011-2014 menunjukkan kematian pada bayi BBLR di Kabupaten Pati tahun 2011-2014 antara 8-10\%. Kematian pada bayi karena BBLR tertinggi terjadi tahun 2012 yaitu sebanyak 10,32\%. Sedangkan persentase terendah terjadi pada tahun 2013 yaitu sebesar 8,61\%. Kematian karena BBLR meningkat pada tahun 2014 menjadi $9,61 \%$.

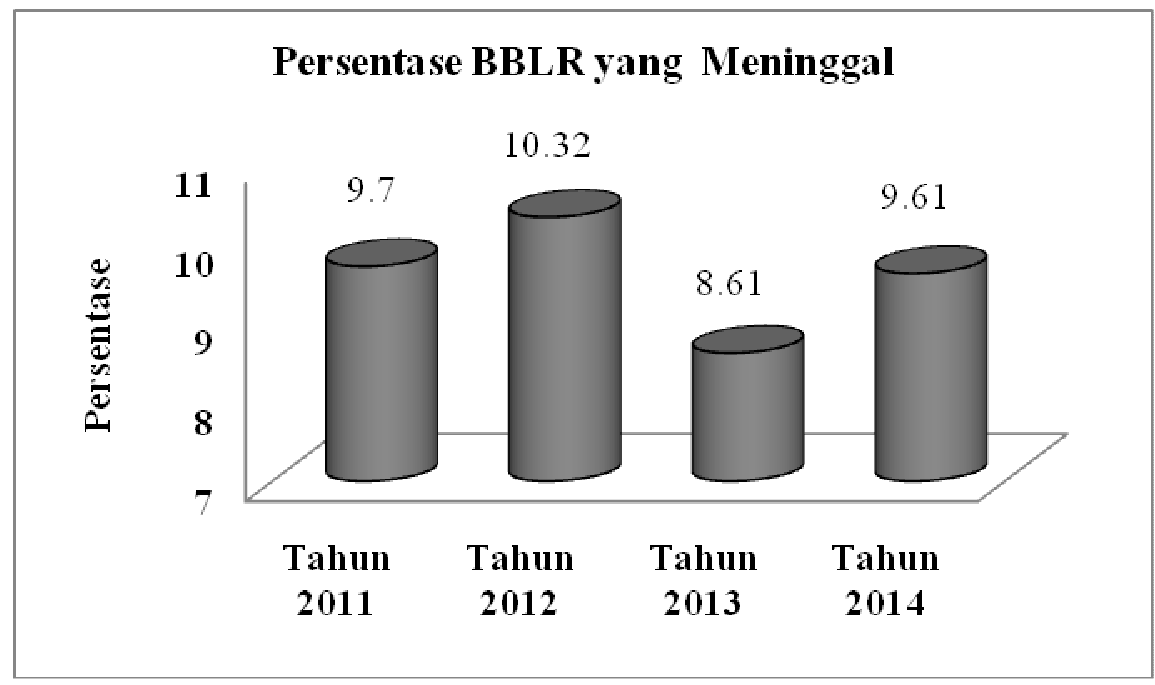

\section{Gambar 2.}

Persentase BBLR yang meninggal di Kabupaten Pati Tahun 2011-2014 Sumber: Dinkes Kab. Pati (2011-2014) 
Berat Badan Lebih Rendah (BBLR) mempengaruhi tumbuh kembang anak di masa berikutnya. Anak yang mengalami BBLR pertumbuhannya akan lambat. Anak dengan BBLR cenderung memiliki kecerdasan yang lebih rendah dari anak yang lahir dengan berat badan normal. Selain itu, bayi yang mengalami BBLR dapat mengalami gangguan mental dan fisik pada usia tumbuh kembang selanjutnya sehingga membutuhkan biaya perawatan yang lebih besar (Sistiarani, 2018).

\section{Kejadian BBLR Berdasarkan Jenis} Kelamin

Data BBLR Kabupaten Pati menunjukkan kejadian BBLR tahun 2012 dan 2013 lebih tinggi pada bayi perempuan, sedangkan pada tahun 2014, BBLR lebih banyak ditemukan pada bayi laki-laki.

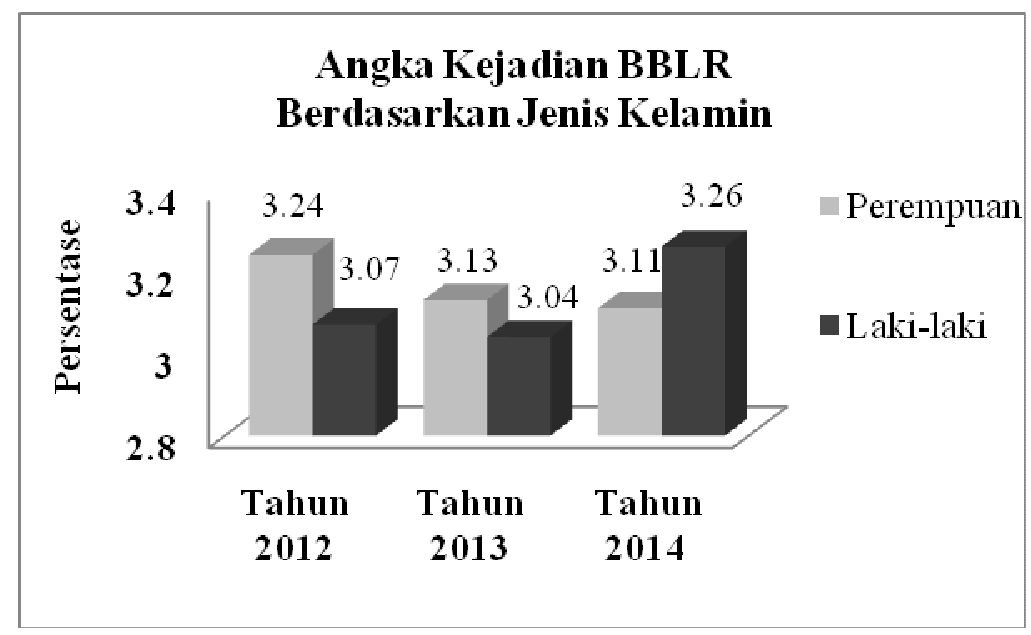

Gambar 3.

Angka Kejadian BBLR di Kabupaten Pati Berdasarkan Jenis Kelamin Tahun 2012-2014 Sumber: Dinkes Kab. Pati (2012-2014)

Gambar 3 menunjukkan adanya perbedaan persentase BBLR pada bayi laki-laki dan bayi perempuan. Namun demikian perbedaan diantara keduanya tidak terlalu jauh, yaitu berkisar antara $0,09 \%$ hingga $0,17 \%$. Perbedaan tertinggi terjadi pada tahun 2012, dimana BBLR pada bayi perempuan lebih tinggi $0,17 \%$ dibandingkan dengan kasus BBLR pada bayi laki-laki, sementara selisih terendah terjadi pada tahun 2013, dimana BBLR pada bayi perempuan hanya berselisih 0,09\% dari BBLR pada bayi laki-laki. Suryadi (2010) menunjukkan adanya hubungan jenis kelamin dengan BBLR, dimana BBLR lebih banyak terjadi pada bayi berjenis kelamin perempuan.
Mulyawan (2009) menyatakan bayi lakilaki saat lahir memiliki rata-rata berat lahir 150 gram lebih berat daripada bayi perempuan, perbedaan ini paling nyata pada umur kehamilan 28 munggu. Penyebabnya diduga akibat stimulasi hormon androgenik atau karena kromosom Y memuat materi genetik yang dapat meningkatkan pertumbuhan janin laki-laki. Janin dengan jenis kelamin lakilaki lebih berat $5 \%$ dan lebih panjang $1 \%$ dibanding dengan janin berjenis kelamin perempuan pada umur kehamilan yang sama. Kondisi ini terjadi karena hormon seks laki-laki dan kromosom Y yang dimiliki laki-laki. Hal ini mulai tampak pada kehamilan 24 minggu. 
Kejadian BBLR Berdasarkan Tempat

Berat Badan Lebih Rendah (BBLR) tersebar di seluruh Puskesmas di Kabupaten Pati. Berdasarkan Kepmenkes No. 128/MENKES/SK/II/2004, Puskesmas adalah Unit Pelaksana Teknis Dinas (UPTD) kesehatan kabupaten/kota yang menyelenggarakan bertanggungjawab pembangunan kesehatan di suatu wilayah. Pembangunan kesehatan merupakan penyelenggaraan upaya kesehatan untuk meningkatkan kesadaran, kemauan, dan kemampuan hidup sehat bagi setiap orang agar terwujud derajat kesehatan masyarakat yang optimal. Persentase BBLR berdasarkan Puskesmas tersaji pada gambar 4.

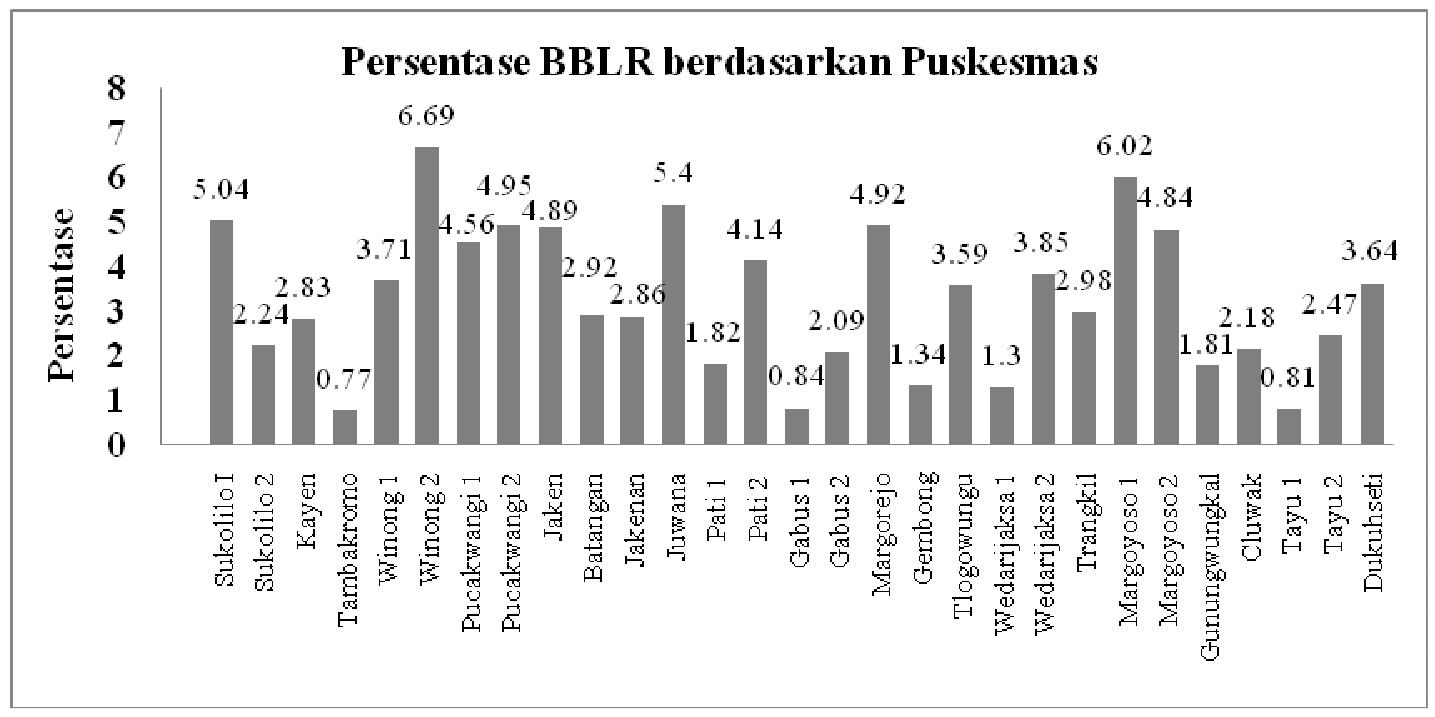

\section{Gambar 4.}

Angka Kejadian BBLR Berdasarkan Puskesmas Tahun 2014

Sumber: Dinkes Kab. Pati (2014)

Jika kejadian BBLR dilihat berdasarkan Puskesmas, maka persentase BBLR di Kabupaten Pati tahun 2014 terbanyak terjadi di Puskesmas Winong 2 yaitu 6,69\%. Sedangkan Puskesmas dengan kejadian BBLR terendah terjadi di Puskesmas Tambakromo yaitu sebesar 0,77\%. Suroso (2013) menunjukkan bahwa Kecamatan Tambakromo termasuk salah satu kawasan tertinggal di Kabupaten Pati dari sisi tingkat kemiskinan, ketersediaan fasilitas SMA, ketersediaan polindes/PKD dan ketersediaan rumah sakit. Sedangkan Kecamatan Winong tertinggal dalam dua aspek pembangunan. Kondisi ekonomi masyarakat dan pendidikan masyarakat yang minim, berpotensi pada status kesehatan masyarakat. Rendahnya status kesehatan masyarakat dapat dilihat dari tingginya angka kejadian BBLR.

\section{Kontribusi BBLR Terhadap Kematian Neonatal}

Kematian neonatal adalah kematian bayi sebelum usia bayi 28 hari. Angka kematian neonatal adalah indikator kesehatan bayi di awal kehidupan. Penyebab kematian neonatal di Kabupaten Pati adalah BBLR, asfeksia, sepsis, kelainan congenital, ikterus, dan lain-lain (Gambar 5). 


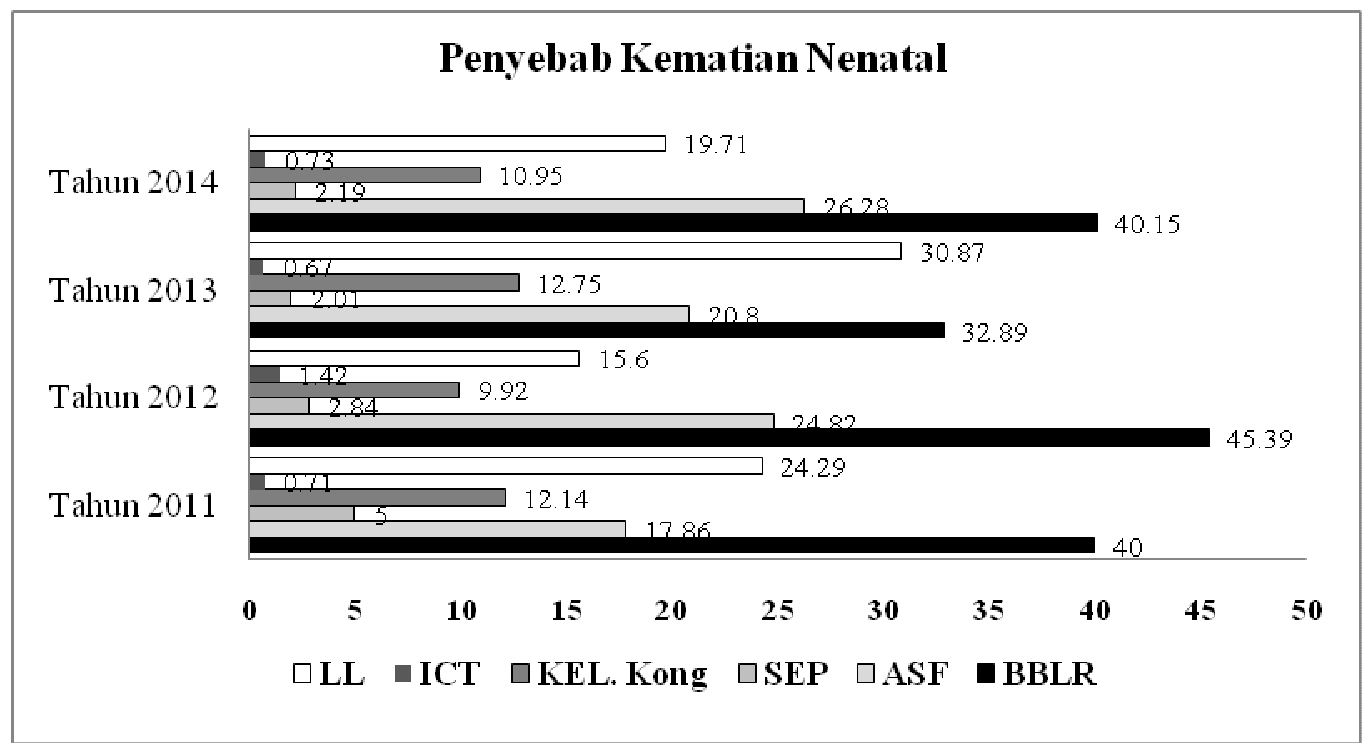

\section{Gambar 5.}

Penyebab Kematian Neonatal Kabupaten Pati Tahun 2011-2014

Sumber: Dinkes Kab. Pati (2011-2014)

Gambar 5 menunjukkan bahwa BBLR menjadi penyebab terbesar kematian neonatal di Kabupaten Pati tahun 2011-2014 yaitu antara 33-45\%. Kontribusi BBLR terhadap kematian neonatal tertinggi terjadi tahun 2012 yaitu $45,39 \%$, sedangkan pada tahun 2014 menurun menjadi $40,15 \%$.

\section{KESIMPULAN DAN SARAN}

\section{Kesimpulan}

Angka kejadian BBLR di Kabupaten Pati tahun 2014 sebesar 3,19\% dan ada kecenderungan meningkat dari tahun sebelumnya. Persentase BBLR pada bayi laki-laki berbeda dengan persentase BBLR pada bayi perempuan, meskipun perbedaannya tidak terlalu jauh yaitu sekitar $0,09 \%$ sampai 0,17\%. Angka kejadian BBLR tertinggi tahun 2014 terjadi di Puskesmas Winong 2 yaitu sebanyak 6,69\%. BBLR menjadi penyebab kematian neonatal terbesar yaitu sekitar $32-45 \%$ setiap tahun.

\section{Saran}

Upaya penurunan BBLR dapat dilakukan melalui peningkatan kemampuan bidan dalam penangangan BBLR melalui pelatihan yang memadai. Perlu meningkatkan pembangunan di kawasan tertinggal untuk meningkatkan status kesehatan masyarakat. Pencegahan dan penanganan BBLR menjadi fokus utama dalam menurunkan angka kematian bayi karena menjadi penyebab terbesar kematian neonatal di Kabupaten Pati.

\section{DAFTAR PUSTAKA}

Anonim, 2013. Epidemiologi BBLR. (http://www.indonesianpublichealth.com/2013/04/ epidemiologi-bblr, diakses 5 Januari 2015).

Saifuddin, A. B. 2001. Buku Acuan Nasional Pelayanan Kesehatan Maternal dan Neonatal. Cetakan II. Jakarta: Yayasan Bina Pustaka Sarwono Prawihardjo 
Departemen Kesehatan Republik Indonesia. 2008. Manajemen Bayi Berat Lahir Rendah (BBLR) untuk Bidan Desa: Buku Acuan. Jakarta.

Dinas Kesehatan Provinsi Jawa Tengah. 2014. Profil Kesehatan Provinsi Jawa Tengah Tahun 2013. Semarang.

Dinas Kesehatan Kabupaten Pati. 2011. Data Dasar Kesehatan Anak. Pati. 2012.

Data Dasar Kesehatan Anak. Pati. 2013. Data Dasar Kesehatan Anak. Pati. 2014.

Data Dasar Kesehatan Anak. Pati

Kementerian Kesehatan Republik Indonesia. 2014. Profil Kesehatan Indonesia Tahun 2013. Jakarta.

Ernawati, A. 2013. Kematian Ibu di Kabupaten Pati: Kinerja dan Antisipasi Kebijakan dan Program. Seri Bunga Rampai. Pembangunan Daerah Berkelanjutan di Kabupaten Pati. Pati: CV Mitra Sejati: 64-92.

Sistiarani, C. 2008. Faktor Maternal dan Kualitas Pelayanan Antenatal yang berisiko terhadap Kejadian Berat Badan Lahir Rendah (BBLR) Studi pada Ibu yang periksa Hamil ke Tenaga Kesehatan dan Melahirkan di RSUD Banyuma. Tesis Magister Ilmu Kesehatan Masyarakat. Semarang: Universitas Diponegoro.

Himawan, A. W. 2006. Hubungan Antara Karakteristik Ibu dengan Status Gizi Balita di Kelurahan Sekaran Kecamatan Gunungpati Semarang. Skripsi. Program Studi Kesehatan Masyarakat. Semarang: Universitas Negeri Semarang.

Suryadi, T. 2010. Faktor Risiko Prognosis Berat Badan Lahir rendah (BBLR) dan Berat Badan Lahir Sangat Rendah (BBLSR) dan Kejadian Lahir Mati di Kota Palembang Tahun 2010. Jurnal Kedokteran dan Kesehatan 42(3): 2925-2932.
Simbolon, D. 2006. Faktor Risiko Sepsis pada Bayi Baru Lahir di RSUD Curup, Kabupaten Rejang Lebong. Buletin Penelitian Kesehatan 36(3): 127-134.

Prawirohardjo, S. 2007. Ilmu Kandungan. Jakarta: Yayasan Bina Pustaka Sarwono.

Asiyah, S., Suswoyo., Mahaendriningtyastuti. 2010.

Karakteristik Bayi Berat Lahir Rendah (BBLR) sampai Tribulan II Tahun 2009 di Kota Kediri. Jurnal Kesehatan Suara Forikes 1(3).

Suroso. 2013. Kebijakan Pembangunan Kawasan Tertinggal di Kabupaten Pati. Jurnal Litbang 9(1): 42-54.

Keputusan Menteri Kesehatan Republik Indonesia Nomor 128 Tahun 2004 tentang Kebijakan Dasar Pusat Kesehatan Masyarakat.

Badan Pusat Statistik Kabupaten Pati. 2014. Pati dalan Angka 2014. Pati.

Mulyawan. 2009. Kejadian BBLR, Karakteristik Ibu, dan Karakteristik Bayi pada Bayi dari Ibu Vegetarian di 17 Kota di Indonesia Tahun 2009 (Analisis Data Sekunder). Skripsi. Fakultas Kesehatan Masyarakat. Jakarta: Universitas Indonesia.

Mutianingsih, R. 2013. Hubungan Antara Bayi Berat Lahir Rendah dengan Kejadian Ikterus, Hipoglikemi, dan Infeksi Neonatorum di RSUP NTB Tahun 2012. Tesis Fakultas Kedokteran. Malang: Universitas Brawijaya.

\section{BIODATA PENULIS}

Aeda Ernawati, SKM, M.Si, Peneliti Muda Bidang Kepakaran Perilaku Kesehatan di Kantor Penelitian dan Pengembangan Kabupaten Pati sejak tahun 2011. Lahir di 22 November 1976 di Purworejo. Pendidikan S1 Fakultas Kesehatan Masyarakat Universitas Diponegoro dan S2 Magister Gizi Masyarakat Universitas Diponegoro. 